Editor

DANIEL J NCAYIYANA

Managing Editor

J P DE V VAN NIEKERK

Deputy Editor

NONHLANHLA P KHUMALO

Assistant Editor

EMMA BUCHANAN

Technical Editors

MARIJKE MAREE

ROBERT MATZDORFF

PAULA VAN DER BIJL

News Editor

CHRIS BATEMAN

Tel. (021) 681-7200

Head of Publishing

ROBERT ARENDSE

Production Manager

EMMA COUZENS

Professional Advertising

BELINDA DOYLE

Tel. (021) 681-7200

E-mail: belinda@hmpg.co.za

Art Director

SIOBHAN TILLEMANS

DTP \& Design

TRAVIS ARENDSE

CLINTON MARK GRIFFIN

Online Manager

GERTRUDE FANI

Distribution Manager

EDWARD MACDONALD

Sales \& Marketing Director

DIANE SMITH

Tel. (012) 481-2069

Email: dianes@samedical.org

Sales Team

LISA REID, AZAD YUSUF,

ANDREW CROSS, KEITH HILL

HMPG Board of Directors

M RAFF (Chair)

R ABBAS

M LUKHELE

D J NCAYIYANA

$T$ TERBLANCHE

M VELLER

Associate Editors

H M COOVADIA (UKZN)

D J DU PLESSIS (Pretoria)

J IPUTO (WSU)

R E KIRSCH (UCT)

B MAYOSI (UCT)

H ODENDAAL (Stellenbosch)

A D ROTHBERG (Wits)

A A STULTING (Free State)

C F VAN DER MERWE (Limpopo)

\section{ISSN 0256-9574}

Website: www.hmpg.co.za

Journal: www.samj.org.za

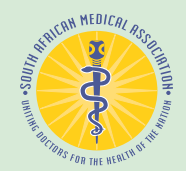

PRINTED BY TANDYM PRINT
February 2010, Volume 100, No. 2

\section{FROM THE EDITOR}

'Truth' in medical journal publishing

71

EDITOR'S CHOICE

\section{CORRESPONDENCE}

State hospitals, academic medicine and the decline of health care in South Africa a cry of support from those who have left to those who stay

Andrew C Don-Wauchope, Andras Karas, Vasudhevan T Chetty, et al.

\section{IZINDABA}

Evidence of doctors' health minister at last

Bridging the divide - anthropologist/sangoma challenges delegates

Lack of oversight on progressive laws fuelling HIV

Male circumcision roll-out certain - now for 'the how' 


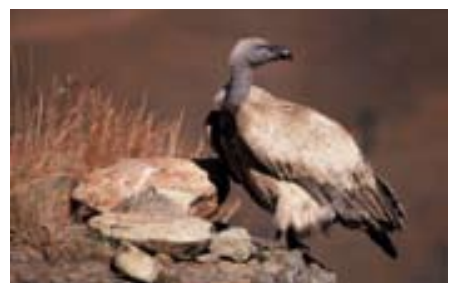

The Cape Vulture Gyps coprotheres is endemic to southern Africa, but its numbers have declined dramatically to the extent that its status is listed as vulnerable in the Red Data Book on birds published in 2000. Its current population numbers a mere 8000 individuals - some breeding colonies have disappeared within living memory. There are several reasons for its decline: the disappearance of the once vast ungulate herds that occurred in its former range, direct persecution by the poisoning of carcasses, electrocution on power lines, disturbance at breeding colonies, and traditional medical or ceremonial uses. Conservation meas are in place, notably the establishoution measures are in place, notably the establishment of oulture supply.

Photo and text: Peter Steyn

Email: peregrine@mweb.co.za

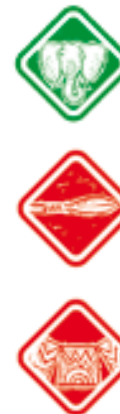

CONTENTS

Wisdom and truth

EDITOR'S

CHOICE

Getting to the point

CORRESPONDENCE/ SCIENTIFIC LETTERS

Communicating thoughts

IZINDABA

Sounding the news

SAMJ

FORUM

Ear to the ground

EDITORIAL

Commentary and

debate

ORIGINAL

ARTICLES

Insight and research

PROFESSIONAL

ADVERTISING

Blowing the horn

\section{SAMJ FORUM}

\section{DRUG ALERT}

Recommendations pertaining to the use of viral vaccines: Influenza 2010

Department of Health

\section{CLINICAL IMAGES}

Intestinal pseudo-obstruction: The massive abdomen and the red herring P Naidoo, S Schwartz, R D Mohanlal, H Greeves

Partial flap avulsion following refractive surgery

Roland R Berger, M D Williams, Clive A Novis

\section{IN MEMORIAM}

Teomar Heyl

Tshimbi Mathivha

\section{EDITORIAL}

Africa's burden of disease: The University of Cape Town Sub-Saharan Africa Centre for Chronic Disease

K C Househam

\section{SCIENTIFIC LETTERS}

HIV-positive kidney transplants for HIV-positive individuals: Attitudes and concerns of South African patients and health care workers Suzanne Gokool, June Fabian, W D Francois Venter, Catherine MacPhail, Saraladevi Naicker

Vuvuzela - good for your team, bad for your ears De Wet Swanepoel, James W Hall III, Dirk Koekemoer 


\section{Original Articles}

Are we winning? Improving perinatal outcomes at a deeply rural district hospital in South Africa

Contents listed in INDEX MEDICUS (MEDLINE). EXCERPTA MEDICA (EM BASE). BIOLOGICAL ABSTRACTS (BIOSIS). SCIENCE CITATION INDEX (SCISEARCH). CURRENT CONTENTS/ CLINICAL MEDICINE

Unless otherwise stated, opinions expressed in the editorial columns of the SAMJ should not be taken as reflecting official South African Medical Association policy. The appearance of advertising in the Association's publications does not denote a guarantee or an endorsement by the Association of the products or the claims made for the products by the manufacturers.

\section{Subscription rates}

Local subscriptions ..................R852.00 p.a. Foreign subscriptions ............R1 920.00 p.a. Single copies .................................... R 75.00 Members of the Association receive the $S A M J$ only on request, as part of their membership benefit.

Subscriptions

Tel. (012) 481-2071

E-mail: members@samedical.org

C Benjamin Gaunt

FAST scanning in the developing world emergency department

Zoë A Smith, Naas Postma, Darryl Wood

The consequences upon patient care of moving Brits Hospital: A case study

C A Pfaff, I D Couper

Cancer prevalence in 129 breast-ovarian cancer families tested for BRCA1 and BRCA2 mutations

C M Schlebusch, G Dreyer, M D Sluiter, T M Yawitch, H J van den Berg,

E J van Rensburg

Plasma levels of DDE/DDT and liver function in malaria control personnel 6 months after indoor residual spraying with DDT in northern Uganda, 2008 G S Bimenya, M Harabulema, J P Okot, Olwa Francis, Myers Lugemwa, A L Okwi

Carboxyhaemoglobin levels in water-pipe and cigarette smokers

Anna Theron, Cedric Schultz, James A Ker, Nadia Falzone

The SAMJ is published on the first of the month by the Health and Medical Publishing Group (Pty) Ltd, Co registration 2004/0220 32/07, a subsidiary of SAMA.

28 Main Road (Cnr Devonshire Hill Road), Rondebosch, 7700

Please submit all letters and articles for publication online at www.samj.org.za

Tel. (021) 681-7200. Fax (021) 685-1395. E-mail: publishing@hmpg.co.za

Website: www.samedical.org

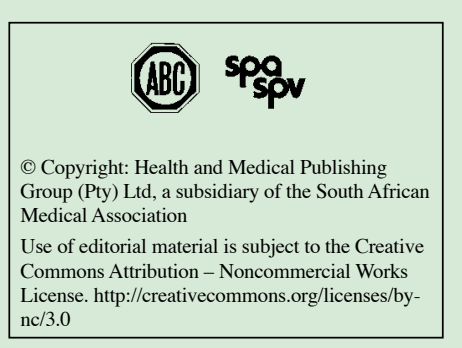

